\title{
Corona-Krise
}

Scott Warren*

\section{Community-building without a Building: Can Libraries Resume Their Place as the Academic Hearts of their Campuses?}

\author{
Reflections on the Consequences of Corona from the Perspective of the Syracuse University \\ Libraries
}

https://doi.org/10.1515/bfp-2020-2093

\begin{abstract}
As academic libraries begin planning to resume on-site services in fall 2020, the effects of COVID-19 will continue to be felt. Trends such as the longstanding shift to primarily online collections will accelerate. Though budget reductions are widely expected, the need for libraries to keep investing in digital infrastructures that enable open distribution of locally held content will be greater than ever, given much of this content, particularly rare and archival collections, became unavailable during quarantine. Libraries will also need to grapple with the impact of social distancing and building restrictions on their identities as the academic heart of their campuses. This reflects the ways in which library spaces have become increasingly busy and essential by providing student services and community building.
\end{abstract}

Keywords: COVID-19; digital libraries

\section{Öffentliche Einrichtungen ohne Räume: Können die wissenschaftlichen Bibliotheken das akademische Herz ihres Campuses wiedergewinnen? \\ Reflexionen über die Konsequenzen der Corona-Pandemie aus der Perspektive der Universitätsbibliothek in Syracuse}

Zusammenfassung: Auch wenn die wissenschaftlichen Bibliotheken bereits begonnen haben, den Service vor Ort neu zu justieren, so werden die Auswirkungen von COVID19 noch länger zu spüren sein. Die Entwicklung der längst ausstehenden Wende zu mehr Online-Sammlungen wird dadurch sogar beschleunigt. Obgleich Budgetkürzungen erwartet werden, ist der weitere Ausbau der digitalen Infrastruktur auf lokaler Ebene dringend geboten. Besonders

*Kontaktperson: Scott Warren, sawarr01@syr.edu der Ausbau der digitalen Nutzung von Rara und Archivsammlungen, die während der Quarantäne nicht verfügbar waren, ist von erheblicher Bedeutung. Die Bibliotheken mussten sich zudem mit den Auswirkungen des Social Distancings und enormen Zugangsbeschränkungen zu ihren physischen Gebäuden, dem Herzstück eines jeden akademischen Campuses, zurechtfinden. Dieser Aufsatz beschreibt die Bibliothek als den Raum, der sich zunehmend als geschäftiger und zentraler Ort für die studentischen Bedürfnisse und die der kommunalen Öffentlichkeit herauskristallisiert hat.

Schlüsselwörter: COVID-19; Digitale Bibliotheken

I was interviewed earlier this year for De Gruyter's blog ${ }^{1}$ where I shared some thoughts on my own experiences during the COVID-19 pandemic and those of the libraries at the American institution where I work, Syracuse University. ${ }^{2}$ The current piece, prompted by the kind invitation of Professor Dr. Elmar Mittler and Professor Michael Seadle, provides an opportunity to extend those thoughts. The blog interview took place in early April when no time frame for re-opening campuses existed in most of the United States. Now it is late May, and like many other institutions, Syracuse University has pledged to offer residential instruction for the fall semester. Consequently, the Libraries are determining how to safely reinstate those services tied to our physical collections and buildings. However, it is unlikely that autumn will mark a return to normal for any research library.

1 https://blog.degruyter.com/librarians-coping-with-covid-19-an-ou tlook-from-the-united-states/.

2 https://library.syr.edu/scrc/index.php, https://www.syracuse.edu. 
To begin, the quarantine threw longstanding developments in academic libraries into sharper relief. For over two decades we had developed parallel infrastructures for online and physical collections, and, to a lesser extent, services. As a result, support for teaching and research could continue largely unabated even as libraries physically shuttered. Services that depended primarily on consulting the expertise of individuals (no matter where they were located) such as liaison (subject) librarians, data specialists, digital scholarship staff, copyright experts, etc. remained mostly viable. However, services predicated upon library spaces or connected to physical collections ground to a halt, for example, circulation of print books and scanning of materials for interlibrary loan. This bifurcation reflected larger societal patterns where much work tied to exchanging information via online networks transitioned fairly seamlessly to home settings while businesses tied to in-person services were severely compromised. Libraries experienced both scenarios because of our parallel operations and modes of collecting. We continue to have one foot in both worlds.

Now academic libraries are grappling with finding ways to successfully re-open their physical spaces while safeguarding both staff and patrons. Longer-term answers will depend on a critical variable - is a vaccine available? If campus populations are inoculated, library services may trend back to early 2020 conditions. If, however, no vaccine is found, libraries will have to find ways to co-exist with COVID-19 for the foreseeable future. Social distancing will remain imperative and services will adjust accordingly, with many implications. In that case, the transition to primarily online collections will only be accelerated by factors old and new such as the longstanding decrease in the use of physical collections (particularly the circulating monograph), the rapid increase in online instruction, and the need to ensure remote access to as much of the collection as possible.

All these conditions suggest that restoring library services this fall is not simply a matter of reversing steps taken in March. Initial re-opening at Syracuse will focus on getting a small group of employees safely back into the main library to resume circulation of print materials, albeit by curb-side pickup, and to initiate limited scanning for ILL or article delivery. Patrons will not be able to come inside for the time being. When the campus population eventually returns in the fall and our libraries hopefully re-open to non-staff, social distancing guidelines will markedly change patrons' experiences. Our main library was consistently the campus building with the most student traffic, but it will likely re-open with dramatically lower limits on building occupancy, Plexiglas shields at service points, a continued focus on online teaching or consultation, and probably some portion of the staff working flexibly from home.

COVID-19 also drove home the need for continued investment to bring rare and special collections online. Though Syracuse has been actively digitizing collections for years, our efforts to date have only touched a small portion of our holdings. Thus, perhaps no aspect of academic libraries was more challenged by the transition to remote work than special or archival collections. Like many libraries, Syracuse developed greater curricular engagement with its remarkable rare materials by promoting in-building classes that gave students a chance to experience rare and unique items firsthand. Seeing an actual letter written by Malcolm $\mathrm{X}^{3}$ or a five hundred-year-old illustrated manuscript draws students in and sparks inquiry. Social distancing and travel restrictions will, however, pose challenges for those who wish to use primary source collections only available by visiting a Reading Room.

Building digital libraries based on content unique to our institutions is therefore more critical than ever if we want to make sure that access to these collections never again becomes so compromised. Success requires robust digital infrastructures (hopefully developed at scale rather than locally), increased local metadata production that can be shared and harvested at scale, and adequate staffing to ramp up production. To date, fully developing such infrastructures has exceeded the capacity of all but the largest research libraries. Even those efforts have had to be largely grant-funded, and may not be sustainable as longterm services (last summer's Red Queen's Race ${ }^{4}$ by Katherine Skinner, Executive Director of the Educopia Institute, remains the best short statement on this dilemma in my opinion).

Clearly then, community solutions that scale are more important than ever, given the growing need for libraries to distribute content themselves. Moreover, this content results from many streams, not just special collections. It can be born digital via library publishing programs or digital humanities projects. It also happens when publica-

3 https://library.syr.edu/scrc/programs/exhibitions/exhi bit/2015-10-black-utopias.php.

4 https://educopia.org/red-queens-race/. Skinner, Kathrine (2019): Why Are So Many Scholarly Communication Infrastructure Providers Running a Red Queen's Race? (In the Red Queen's race one must keep running just to stay in place). The blog post reports and reflects the findings of the survey "Mapping the Scholarly Communication Landscape - 2019 Census" (https://educopia.org/2019-Census/) which provides deep insights in the organizational and technical infrastructures of Scholarly Communication Resources. 
tions are deposited into institutional repositories. Regardless of the source, all locally managed digital collections have similar preservation needs and highlight a growing function for libraries - that of producing, hosting, or distributing digital content themselves, not just licensing it from others. As a member of the Board of the Library Publishing Program 5 , I am keen to see libraries grow their capacity in this area and believe it is a strategic necessity, now more than ever.

The challenge, of course, is that the need for greater investment comes at a time of nearly universally retrenched higher education budgets. What will happen? The fates of American universities, whether public or private, depend on students enrolling in similar numbers as they did in the past, as most are largely tuition dependent. Even private institutions with favorable financial situations will experience belt tightening. As I write, we at SU are implementing a $5 \%$ reduction across our entire library budget. Collection building will be impacted, and investments will likely slow in all areas, ranging from improving our physical spaces and hiring new staff to producing, delivering, and curating digital content based on local collections.

There is also cause for concern beyond the immediate operational challenges of reopening or the adverse impact of fiscal austerity on digital library projects. I worry about how libraries will continue to build relationships and remain visible on campus if we cannot rely on our spaces as much. Libraries have long argued they serve as so much more than repositories of information. We proudly stake our claim as the intellectual heart of the community. That heart, however, remains both physically and symbolically incarnated in our buildings. The past few decades of innovative library design, renovation, and construction shifted our spaces away from the premise of primarily holding physical collections to the mission of bringing people, particularly students, together in academic pursuits and nurturing community. Libraries evolved beyond serving as sites to house vast print collections by adding learning commons that enabled students to work together and then incorporating spaces best thought of as studios where new knowledge products are created.

In general, those strategies worked. Despite widespread claims that online information would eliminate physical libraries, the opposite happened. Academic libraries that successfully redeveloped their spaces to offer new services became busier than ever. But what happens if hard brakes are slammed on our ability to foster commu-

5 https://librarypublishing.org/. nity through our buildings? Libraries are more than operational spaces. They bring people and ideas together, and we must attend to these functions even when the buildings are no longer fully accessible. However, libraries will find it challenging to reinstate some of the activities that helped drive these vital exchanges.

Libraries will have to think creatively about effective ways to replicate a sense of community and engagement online. Our rich programming for faculty and graduate students, such as speaker series and receptions celebrating and furthering scholarly achievement, will likely be curtailed. Students may encounter limitations on flexible study spaces and on innovative service points that have markedly contributed to their success such as centers for entrepreneurship ${ }^{6}$ or undergraduate research ${ }^{7}$ (both of which are found in Syracuse's main library). Libraries will need to heighten their focus on strategic communication and make deft use of social media. We will need to listen to patrons' concerns and try to develop new workarounds. Listening has always mattered for libraries but will assume even greater importance now, given the rapidly evolving conditions that will guide academic life this fall.

I am optimistic about our ability to do all this. One positive consequence of working remotely has been how we have allowed ourselves to get to know one another in a more holistic way. Communication has become far more accepting of personal circumstances and more responsive to the human need for genuine connection. In mid-May, the Syracuse University Libraries replaced our regular SpringFest (a gathering with posters by staff highlighting what they have been working on), with an online community meet-up where we shared various hidden talents including several music performances as well as personal collections of miniature flags and typewriters. It was a resounding success because it demonstrated how libraries can quickly adapt to using online methods to drive community experiences. Given such willingness to experiment and that service is in the DNA of those who work in libraries, I believe we will find ways to connect our campus communities, even if we cannot bring them together inside our libraries as much as we did before.

Finally, as we plan the next steps for libraries, we will inevitably make mistakes. Even the best planning cannot satisfy every contingency. Still, I am confident some measure of physical services will resume as we sort out new workflows and ways of doing business. The transition to

6 https://launchpad.syr.edu/.

7 https://news.syr.edu/blog/2019/03/25/the-source-creates-new-op portunities-for-undergraduate-research/. 
primarily online collections, the push for open access, particularly for scientific research articles, and the development of robust digital library infrastructures at scale will accelerate, to the extent that funding challenges can be overcome. Meanwhile, we will have to rethink models and practices such as dense seating for group work and student experiences built primarily around service spaces inside library buildings. By providing excellent services and nurturing relationships, libraries will seek visionary ways to remain effective centers for their campus communities, even under social distancing restrictions.

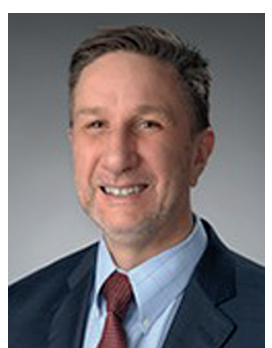

\section{Scott Warren}

Syracuse University Libraries

222 Waverly Avenue

Syracuse, NY 13244

USA

sawarr01@syr.edu 